\title{
Performance Evaluation of Solar Operated Push Type Sprayer
}

\author{
Chandrashekar*, J. Neeraja and V. Raghavendra \\ College of Agricultural Engineering, UAS, Raichur, Karnataka, India \\ *Corresponding author:
}

\begin{tabular}{|c|}
\hline Keywords \\
\hline $\begin{array}{l}\text { Solar panel, } \\
\text { Sprayer, } \\
\text { Conventional } \\
\text { energy source and } \\
\text { operating pressure }\end{array}$ \\
\hline Article Info \\
\hline $\begin{array}{l}\text { Accepted: } \\
12 \text { November } 2018 \\
\text { Available Online: } \\
10 \text { December } 2018\end{array}$ \\
\hline
\end{tabular}

A B S T R A C T

The use of photovoltaic (PV) module for push type solar operated sprayer is one of the most promising techniques in solar energy application. The push type solar operated sprayer consists of a PV module of $20 \mathrm{~W}$ and two diaphragm type pumps of $0.03 \mathrm{hp}$ each. The system was tested for its performance in terms of variation is in nozzle discharge for different operating pressure and height. It was observed during normal climatic condition the PV module produced power in the range of $7.1 \mathrm{~W}$ to $17.29 \mathrm{~W}$ from $10: 00 \mathrm{am}$ to $4: 00 \mathrm{pm}$ in the month of December 2015.It was also observed that the nozzle discharge initially was found to be less during morning 10:00am later on gradually increased up to 12 noon and again found to be decreasing till evening 4:00 pm due to low solar intensity. We also observed that the discharge obtained from two types of hollow cone nozzles which are two slits and four slits for different operating pressure of 2,3 and $4 \mathrm{~kg} / \mathrm{cm}^{2}$ at different spray height 49, 51and $53 \mathrm{~cm}$ respectively, but the required discharge rate was obtained from two slit hollow cone nozzle at an operating pressure of $2 \mathrm{~kg} / \mathrm{cm}^{2}$ rather than four slits hollow cone nozzle. The actual and theoretical field capacity of push type solar sprayer were $0.29 \mathrm{ha} / \mathrm{h}$ and $0.32 \mathrm{ha} / \mathrm{h}$ for field bean crop with forward speed of $0.53 \mathrm{~m} / \mathrm{s}$ respectively. It was observed that, the cost of operation of solar operated push type low clearance sprayer was found to be Rs.38.5/h. The push type solar sprayer is working efficiently in row crops and vegetable crops by adjusting swath width as well as height of boom depending upon requirement.

\section{Introduction}

Agriculture plays a vital role in Indian economy, as about $50 \%$ of total India's population depends on agriculture as their primary source of livelihood. In this agriculture sector there is a lot of field work, such as tillage operation, weeding, sowing, harvesting, etc. Energy-demand is one of the major threats for our country because of increased population. Finding solutions, to meet the energy-demand is the great challenge for social scientist, engineers, entrepreneurs and industrialist of our country. Applications of nonconventional energy are the only alternate solution for meeting out energy demand. Apart from these operations, spraying is also an important operation to be performed by the farmer to protect the cultivated crops from insects, pests, funguses and diseases for which various insecticides, pesticides, fungicides and nutrients are 
sprayed on crops for protection. Manually operated sprayers are operated by the person but drawback is it causes fatigue to operating person and hence cannot be used for longer time and fuel operated sprayers are operated using fossil fuels but drawback is its cost of operation is high due to fuel used and also emits pollutant gases which leads to environmental issues and Electrical sprayers are operated on electricity for charging the battery which drives the pump but drawback is it can't be used in some of rural areas due to insufficient supply of electricity. To overcome these drawbacks we could think on nonconventional energy sources like wind energy, solar energy, tidal energy, etc. considering above mentioned problems we have developed a solar operated push type sprayed and also done its performance evaluation.

\section{Materials and Methods}

In this chapter we are explaining about the power train of push type solar sprayer and its constructional details, calibration in laboratory and also in filed. The laboratory Calibration of the developed machines involves Nozzle discharge, Spray uniformity coefficient, Spray droplet size and Analytical calculation of solar panel current and discharging time of battery. The field calibration of this developed machine involves Application rate, field capacity and field efficiency.

\section{Power transmission system}

\section{Calibration of push type solar sprayer in laboratory}

The sprayer is calibrated to achieve recommended application rate before taking it to the field. Two hollow cone nozzles of different slits are been tested in the lab by considering three different operating pressures. For calibration the following tests were conducted in laboratory:
Nozzle discharge

Spray uniformity coefficient

Spray droplet size

Analytical calculation of solar panel current and discharging time of battery

\section{Nozzle discharge}

The discharge from the hollow cone nozzle was measured at three different operating pressures and spray height using a spray patternator. The spray patternator is an instrumental setup used to quantify the amount of spray emitted from a spray nozzle and visualize its pattern by operating at different spray height and operating pressures. The patternator consists of number of slots and the discharge obtained at each slot was measured and tabulated.

\section{Spray uniformity coefficient}

Along with discharge rate, spray uniformity coefficient is considered as an essential factor in determining the effectiveness of the spraying. Therefore uniformity of the sprayer should be assessed in order to provide a good deposition of spray liquid uniformly over the whole height of the crop canopy. So the uniformity coefficient of hollow cone nozzle is calculated using the discharge obtained from patternator.

The coefficient uniformity is calculated by the following equation

$$
\mathrm{C}_{\mathrm{u}}=\left(1-\frac{\Delta \overline{\bar{x}}}{\bar{x}}\right) \times 100
$$

Where,

$\mathrm{C}_{\mathrm{u}}=$ coefficient of uniformity (\%)

$\bar{x}=$ average discharge rate $(\mathrm{Lt} / \mathrm{min})$

$\Delta \bar{x}=$ Standard deviation $(\mathrm{Lt} / \mathrm{min})$ 


\section{Spray droplet size}

To measure the droplet size of hollow cone nozzle 3-magnesiun coated slides were made as replications. Slides were made by allowing magnesium oxide smoke from a piece of burning magnesium ribbon of about $20 \mathrm{~cm}$ to condense on the underside of a glass microscope slide. Water mixed with suitable coloring agent was allowed to spray on each slide at three different operating pressures of 2, 3, and $4 \mathrm{~kg} / \mathrm{cm}^{2}$ respectively. After exposure to spray, slides were retained for several hours without deterioration. The slides were handled by the ends that were not coated with magnesium oxide to avoid the disturbances to droplets craters. The size of the craters on each slide was measured using "Trinocular Microscope" in laboratory.

Analytical calculation of panel current and discharging time of battery

Current (I). The current produced by the solar panel (I) was calculated by the knowing the maximum power $(\mathrm{P})$ of the solar panel and the voltage rating $(\mathrm{V})$ of the battery that is given by

$$
\mathrm{I}=\frac{\mathrm{P}}{\mathrm{V}}
$$

Charging time $(\mathbf{T})$. The charging time was computed by taking the ratio rating of the battery in ampere hour (Ah) to the total current consumed by the solar panel.

$$
\mathrm{T}=\frac{\text { Battery rating in ampere hour }}{\text { Total current consumed by thesolar panel }}
$$

\section{Field evaluation of push type solar sprayer}

\section{Application rate}

The sprayer application rate depends on discharge rate, swath width, and speed of operation.

The application rate is calculated by the following equation

$$
\mathrm{A}=\left(\frac{\mathrm{Q}}{\mathrm{SXW}}\right)
$$

Where,

$\mathrm{A}=$ Application rate, $\mathrm{Lt} / \mathrm{ha}$

$\mathrm{Q}=$ Discharge rate, $\mathrm{Lt} / \mathrm{min}$

$\mathrm{W}=$ Swath width, $\mathrm{m}$

$\mathrm{S}=$ Speed of operation, $\mathrm{m} / \mathrm{s}$

\section{Field capacity}

The sprayer field capacity depends on swath width and speed of operation.

The field capacity is calculated by

$$
\mathrm{A}_{\mathrm{fc}}=\frac{(\mathrm{SXW})}{10}
$$

Where,

$\mathrm{A}_{\mathrm{fc}}=$ Actual field capacity, ha/h

$\mathrm{T}_{\mathrm{fc}}=$ Actual field capacity, ha/h

The application rate is calculated $(\mathrm{A})$

$$
\mathrm{A}=\left(\frac{\mathrm{Q}}{\mathrm{SXW}}\right)
$$

Where,

$\mathrm{A}=$ Application rate, $\mathrm{Lt} / \mathrm{ha}$

$$
\begin{aligned}
& \mathrm{Q}=\text { Discharge rate, } \mathrm{Lt} / \mathrm{min} \\
& \mathrm{W}=\text { Swath width, } \mathrm{m} \\
& \mathrm{S}=\text { Speed of operation, } \mathrm{m} / \mathrm{s}
\end{aligned}
$$

\section{Results and Discussion}

The laboratory test was carried out to study the uniformity of spray of given nozzle and field evaluation conducted to evaluate the performance of push type solar sprayer is presented and discussed in this chapter. During the laboratory test parameters such as operating pressure, spray height and nozzle discharge are tabulated, whereas during the field experiment observations such as time, 
solar intensity, temperature, voltage, current, power discharge are recorded and explained below (Fig. 1-4).

\section{$\mathbf{N}_{1}$-Hollow cone nozzle (4-Slit Type)}

Variation of discharge with respect to varying height at constant pressure

Variation of nozzle discharge with respect to increase in spray height at constant operating pressure is presented in the figure 5. A graph is plotted between nozzle discharge v/s spray height keeping pressure as constant at $4 \mathrm{~kg} / \mathrm{cm}^{2}$. So from graph we can infer that as the height of spray increases the discharge from spray nozzle decreases covering a swath width of $90 \mathrm{~cm}$ and Uniformity coefficient is about $99.85 \%$.

Variation of discharge with respect to varying pressure at constant spray height

Variation of nozzle discharge with respect to increase in operating pressure at constant spay height is presented in the figure 6 .

A graph is plotted between discharge v/s pressures keeping spray height as constant at $39 \mathrm{~cm}$. So from Variation of nozzle discharge with respect to increase in spray height at constant operating pressure is presented in the table 1. From the graph we can infer that as the pressure increases the discharge from spray nozzle also increases covering a swath width of $90 \mathrm{~cm}$ and Uniformity coefficient is about $66.06 \%$.

Fig.1 Block diagram of power transmission system in solar operated push type sprayer

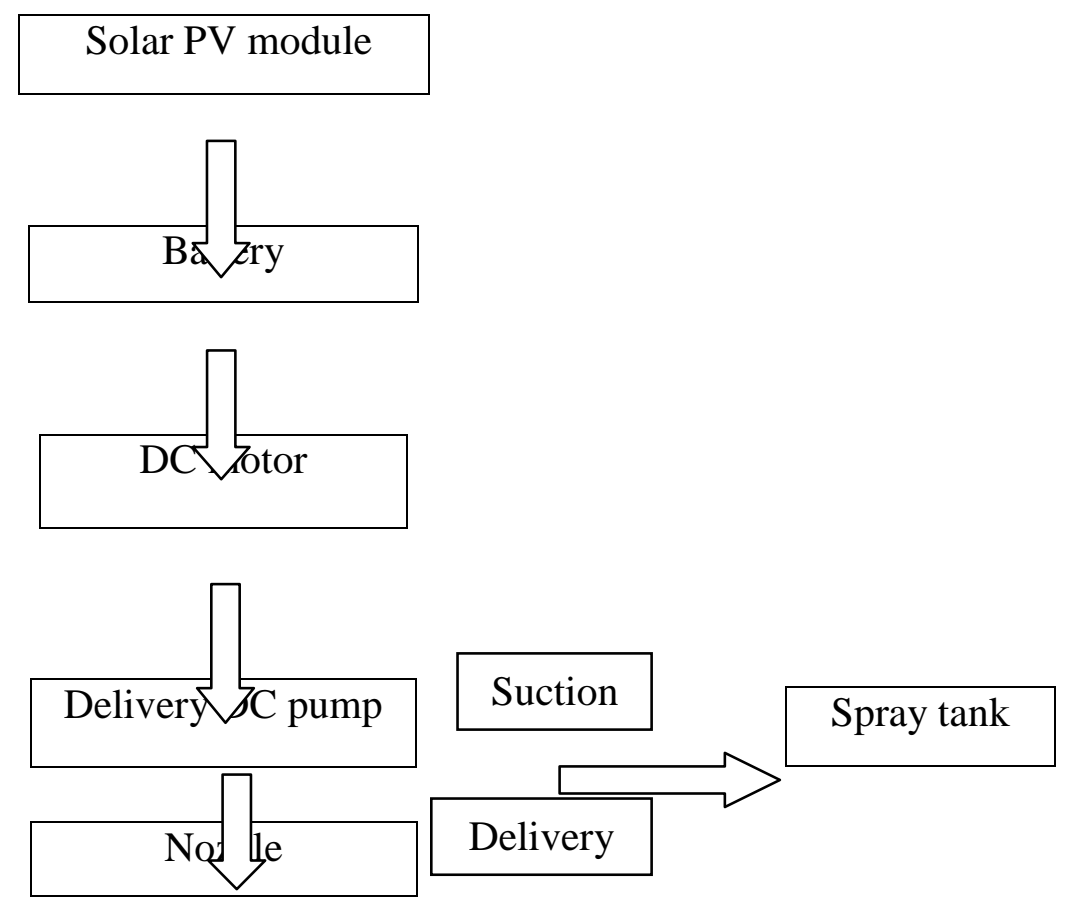


Table.1 Construction details of solar operated push type sprayer

\begin{tabular}{|c|c|c|}
\hline SL.NO & PARAMETERS & DETAILS \\
\hline \multirow[t]{5}{*}{1.} & Panel description & \\
\hline & (a) maximum power $\left(\mathrm{P}_{\max }\right)$ & $20 \mathrm{~W}$ \\
\hline & (b) maximum power voltage $\left(\mathrm{V}_{\mathrm{mP}}\right)$ & $16 \mathrm{~V}$ \\
\hline & (c) maximum power current $\left(\mathrm{I}_{\mathrm{mp}}\right)$ & $1.25 \mathrm{~A}$ \\
\hline & (d) no: of panels & 1 \\
\hline \multirow[t]{5}{*}{2.} & Description of DC motor & \\
\hline & (a) power(P) & $25.2 \mathrm{~A}$ \\
\hline & (b) voltage(V) & $12 \mathrm{~V}$ \\
\hline & (c) current(I) & $2.1 \mathrm{~A}$ \\
\hline & (d) no: of motors & 2 \\
\hline \multirow[t]{4}{*}{3.} & Description of DC pump & \\
\hline & (a) type of pump & Diaphragm pump \\
\hline & (b) discharge(Q) & $2.5 \mathrm{Lt} / \mathrm{min}$ \\
\hline & (c) pressure $\left(\mathrm{P}_{\mathrm{r}}\right)$ & $80 \mathrm{psi}\left(5.624 \mathrm{~kg} / \mathrm{cm}^{2}\right)$ \\
\hline \multirow[t]{5}{*}{4.} & Battery description & \\
\hline & (a) type of battery & Sealed Lead Acid Dry Type \\
\hline & (b) voltage $(\mathrm{V})$ & $12 \mathrm{~V}$ \\
\hline & (c)current(I) & $7.2 \mathrm{~A}$ \\
\hline & (d) power(P) & $86.4 \mathrm{WP}$ \\
\hline \multirow[t]{3}{*}{5.} & Nozzle description & \\
\hline & (a) nozzle type & Hollow cone( 2 slit and 4-slit) \\
\hline & (b) orifice diameter $\left(\mathrm{d}_{\mathrm{o}}\right)$ & $2 \mathrm{~mm}$ \\
\hline \multirow[t]{3}{*}{6.} & Tank and hose pipe description & \\
\hline & (a) tank capacity(c) & $32 \mathrm{Lt}$ \\
\hline & (b) diameter of hose pipe $\left(d_{p}\right)$ & $16 \mathrm{~mm}$ \\
\hline
\end{tabular}


Fig.2 A view of solar operated push type sprayer

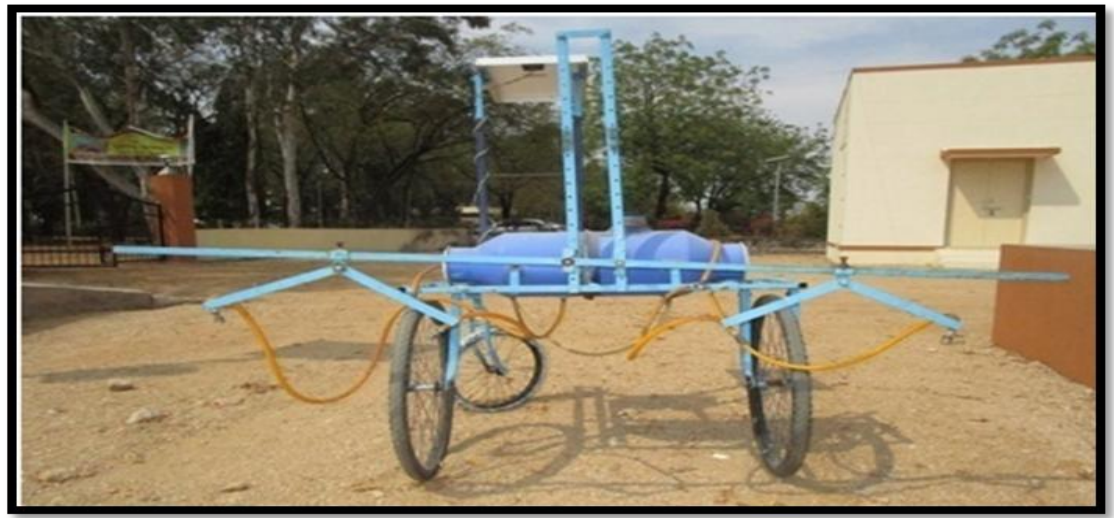

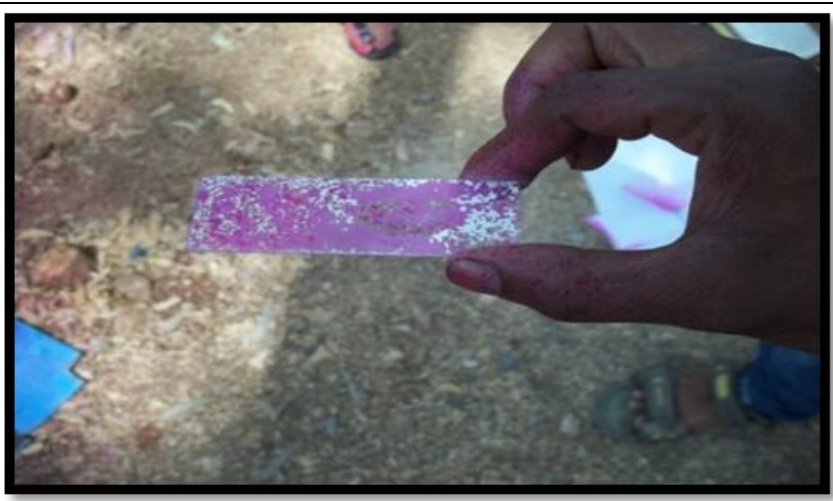

Fig.3 Measurement of spray droplet size by magnesium oxide coated glass slide

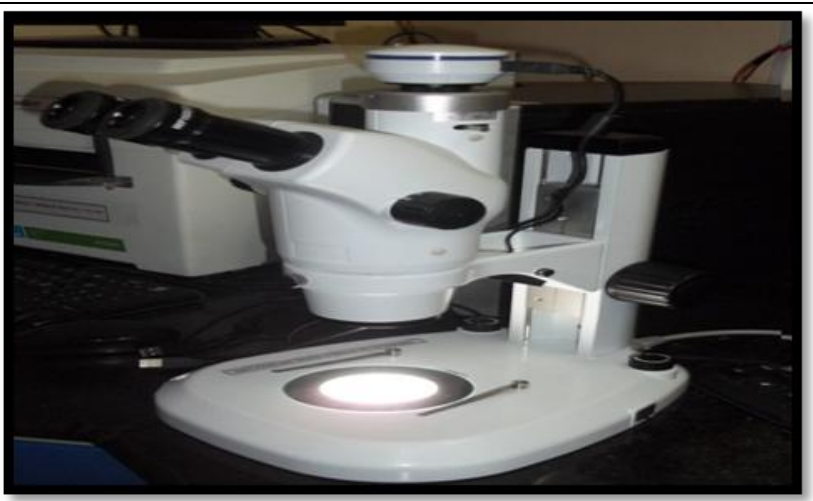

Fig.4 A view of trinocular microscope

Fig.5 Variation of discharge with respect to varying height at constant pressure

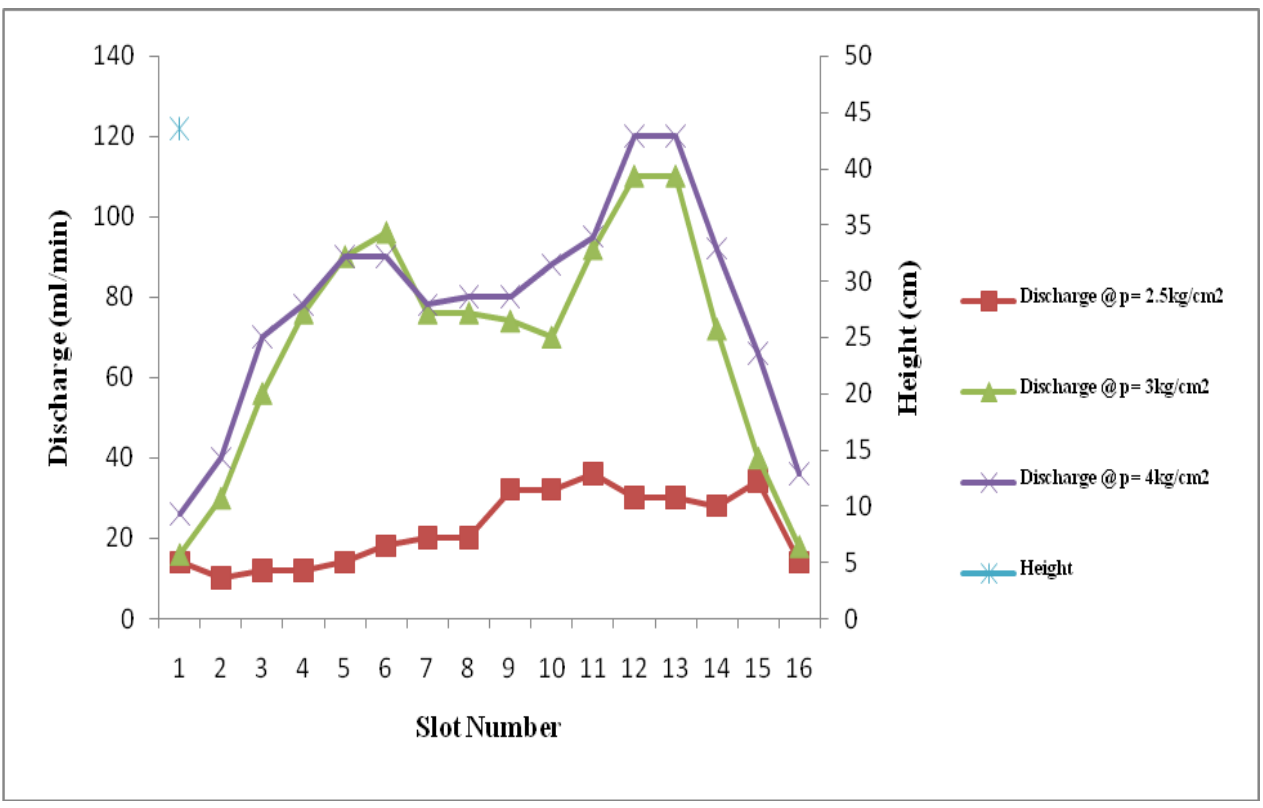


Fig.6 Variation of discharge with respect to varying pressure at constant spray height

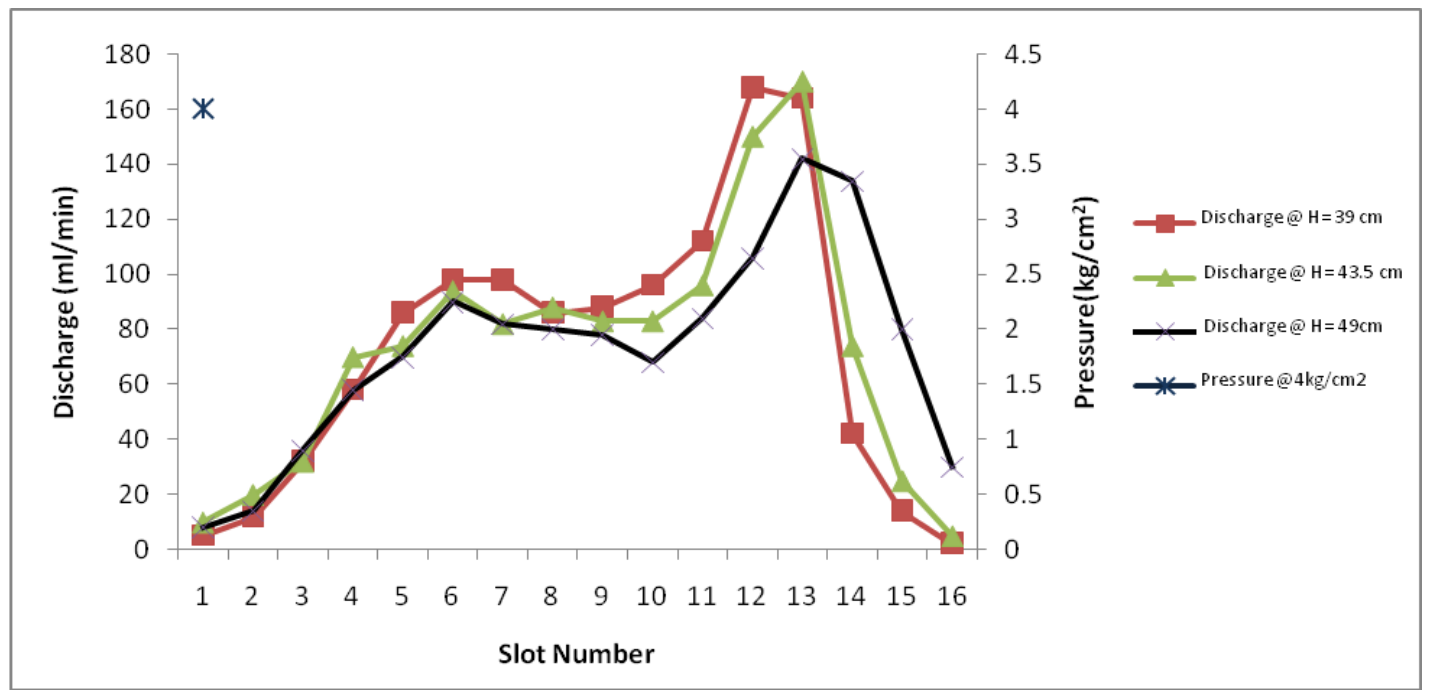

The summary and conclusion are as follows:

The push type solar sprayer was developed to utilize the available solar energy. The sprayer is mainly used for spraying row crops due to the low clearance. The laboratory test carried out to study the uniformity of spray of hollow cone nozzle using spray patternator by operating at different operating pressure and spray height and evaluated the performance of solar operated push type sprayer in field at an operating pressure of $2 \mathrm{~kg} / \mathrm{cm}^{2}$ having hollow cone nozzle with a pump capacity of 2.5 $1 /$ min. The effects of operational parameters were analyzed by plotting graphs between one parameter with respect to another.

Based on the laboratory test and performance evaluation in the field, the following conclusions are drawn out of the study.

It was observed that the discharge rate increased by increasing the operating pressure.

It was observed that the discharge rate increased as the pump capacity was increased. It was found that the discharge rate was depends upon the size of nozzle.
The spray uniformity was increased with increase in operating pressure.

It was observed that the droplet size is depends on the operating pressure. As the operating pressure increases the size of the droplets were decreased.

The discharge rate of the sprayer was high during the period from 12 noon to $1 \mathrm{pm}$. This is because of the solar intensity was high i.e. 991 and $980 \mathrm{~W} / \mathrm{m}^{2}$, respectively. The minimum was $580 \mathrm{~W} / \mathrm{m}^{2}$ in the evening $5 \mathrm{pm}$. The current produced by the panel was 1.25 A. so to discharge the 7.2 Ah battery the time required was $4.31 \mathrm{~h}$.

The capacity of fully charged battery covers an area of 1.9 ha.

The actual and theoretical field capacity has been worked out as $0.29 \mathrm{ha} / \mathrm{h}$ and $0.32 \mathrm{ha} / \mathrm{h}$ for field bean crop with forward speed of $0.528 \mathrm{~m} / \mathrm{s}$ and $0.583 \mathrm{~m} / \mathrm{s}$ respectively. Thus the overall field efficiency of push type solar sprayer is $90.62 \%$.

The diameter of droplet size of hollow cone nozzle was found to be $2.8 \mu \mathrm{m}$ during lab experiment with the help of "Trinocular Microscope".

It was observed that, the cost of operation of solar operated push type low clearance 
sprayer was found to be Rs.38.5/h.

Total cost for one unit of push type solar sprayer is about Rs12685/-

\section{References}

Ashish P Patil, Shivgauri V Chavan, Amol P Patil and Mandar H Geete., 2014. Performance Evaluation of Solar Operated Snapsack Sprayer, www.indianjournasl.com, 38(3).

Ashry, A.S, Gendy. H.A and Abo Naga. 2007. Development and performance evaluation of a greenhouse pesticide sprayer, annual conference of the ministry society of agriculture engineering, 1(2):1466-1477.

Awulu J.O and Sohotshan P.Y., 2012. Evaluation of a Developed Electrically Operated Knapsack Sprayer. International journal of science and technology.2(11):2224-3577.

Das. N, Maske. N, VinayakKhawas S. K. Chaudhary., 2015. Agricultural fertilizers and pesticides sprayers. International journal for innovative research in science \& technology - a review.1(11).

Ejaz. K, Abdul Tahir. R, Faizan-Ul-Haq Khan, Tariq. M., 2004. Performance Evaluation of Modified Self-Leveling Boom Sprayer, International journal of agriculture \& biology. 6(4):636-638.

Jamar, Mostade, Huyghebaert, Pigeon and Lateur., 2010.Comparative performance of recycling tunnel and conventional sprayers using standard and driftmitigating nozzles in dwarf apple orchards. Crop Protection, www.elsevier.com 29: 561-566.

Joshua. R, Vasu. V and Vincent. P, 2010.Solar Sprayer Agriculture Implement International Journal of Sustainable Agriculture. 2 (1): 16-19.

Kulkarni. S, Hasurkar. K, Kumbhar. R, Gonde. A, Raut A.S., 2015. Review of solar powered pesticide sprayer. International journal of research in advent technology, 3(4): 2321-9637.1 No. 2: 30-341. 1 No. 2: 30-34 (

Padmanathan. P.K and Kathirvel. K., 2007. Performance Evaluation of Power Tiller Operated Rear Mounted Boom Sprayer for Cotton Crop. Research journal of agriculture and biological sciences, 3(4): 224-227.

Parida. B, Iniyan. S, Goic. R., 2011. A review of solar photovoltaic technologies, sciencediect.com, 15:1625-1636.

Robson Sasaki, Martins Teixeira, DellyFilho, Carlos Juniocesconetti, Anderson Candido Silva, Daniel Mariano Leite., 2014. Development of a solar photovoltaic backpack sprayer, www.ufpi.br/comunicata, 5(4): 395-401.

Shivarajakumar and Parameswaramurthy. 2014. Development of Wheel Driven Sprayer, International Journal of Engineering Research Online a Peer Reviewed International Journal. 2 (3): 2321-7758.

Smith and Wilkers., 1977. Determine the effect of nozzle type on the control of insects and found that the hollow cone nozzle. International Journal of Agricultural Engineering 2(5): (756761).

Srivastava S.P and Surat P.S, Solar 2013. Energy and Its Future Role in Indian Economy., International journal of environmental science, 4 (3) 2231-1289.

Swapnil L. Kolhe N.B, Gajbhiye V.B and Deshmukh.,2014.Eco-friendly Mechanically Operated Multipurpose Spray Pump, International Journal of Research in Advent Technology,2 (2).

Tekade M.P, G.S. Kadam G.S, Dhande K.G and Powar A.G., 2008.Performance evaluation of tractor mounted tall tree air carrier sprayer for spraying on mango orchard, International Journal of Agricultural Engineering., 1(2):30-34. 
Tekale D.D, Kawade S.C and Sawant. B.P., 2007.Performance Evaluation of Air Carrier Sprayer for Orange Orchard, Karnataka Journal Agriculture Science., 20(2): 330-332.

Veerangouda. M, Prakash. KV, Ram. JJ and Neelakantayya. G., 2010. Performance evaluation of bullock drawn sprayers for cotton crop, Karnataka Journal. Agriculture Science.23 (5): (756-761).
Vipul K. Singh, Jyoti, M.M. Krishna Reddy, Kesavachandran, S.K. Rastogi, M.K.J. Siddiqui., 2007. Biomonitoring of organochlorines, glutathione, lipid eroxidation and cholinesterase activity among pesticide sprayers in mango orchards, www.sciencedirect.com37(2): 268-272.

\section{How to cite this article:}

Chandrashekar, J. Neeraja and Raghavendra, V. 2018. Performance Evaluation of Solar Operated Push Type Sprayer. Int.J.Curr.Microbiol.App.Sci. 7(12): 1448-1456. doi: https://doi.org/10.20546/ijcmas.2018.712.172 